\title{
22. EARLY CRETACEOUS BELEMNITES FROM THE EAST INDIAN OCEAN AND THEIR PALEOBIOGEOGRAPHIC IMPLICATIONS ${ }^{1}$
}

\author{
Jörg Mutterlose ${ }^{2}$
}

\begin{abstract}
Five Holes (761B, 762C, 763B, 763C, 766A) were drilled during Legs 122 and 123 that yielded Lower Cretaceous (Berriasian-Hauterivian) belemnite guards. These include the following species: Belemnopsis cf. jonkeri, Belemnopsis. ex gr. moluccana s.1., (?)Hibolithes sp., and Duvalia cf. sakalava. Their systematic and stratigraphic position is discussed. The Berriasian-Lower Valanginian Belemnopsis assemblages of Holes 761B, 763B, and 763C show close affinities to the Belemnopsis moluccana group s.1. described from Indonesia. These faunas are included in the Neocomian Indo-Pacific Subprovince. The Duvalia observed in Hole $766 \mathrm{~A}$ indicates faunal links to Madagascar for the Hauterivian. The paleobiogeographic importance of the belemnite faunas is discussed.
\end{abstract}

\section{INTRODUCTION}

During Legs 122 and 123, eight holes were drilled (Sites 759-766) off northwest Australia. These sites cover two complete transects from a continental margin to an old ocean basin. One transect covers the Wombat Plateau and the adjacent Argo Abyssal Plain; the second transect, farther to the south, crosses the Exmouth Plateau and the Gascoyne Abyssal Plain (Fig. 1). The principal goals of Leg 122 (Sites 759-764) and Leg 123 (Sites 765 and 766) were (1) to decipher the drifting and early rifting history of the northwestern Australian margin and (2) to describe the initial opening of the Indian Ocean. Four of the sites (Holes $761 \mathrm{~B}, 762 \mathrm{C}, 763 \mathrm{~B}, 763 \mathrm{C}$, and 766A) yielded Lower Cretaceous belemnite guards, which are described here.

\section{MATERIAL AND STRATIGRAPHY}

Holes $761 \mathrm{~B}$ and $761 \mathrm{C}\left(16^{\circ} 44.23^{\prime} \mathrm{S}, 115^{\circ} 32.10^{\prime} \mathrm{E}\right.$; water depth $=2188.80 \mathrm{~m}$ ) are located about $350 \mathrm{~km}$ northwest of the coast of western Australia, on the central part of the Wombat Plateau. Belemnite guards are common in lithologic Unit III. a yellowishbrown to dark brown ferruginous sandstone (Haq, von Rad, O'Connell, et al., 1990). This unit, which covers an interval from Cores $122-761 \mathrm{~B}-30 \mathrm{X}-1,0 \mathrm{~cm}$, to $-31 \mathrm{X}-1,0 \mathrm{~cm}$, and Cores 122 761C-10R-1, $40 \mathrm{~cm}$, to 761C-11R-1, $0 \mathrm{~m}$, has a thickness of 4.1 m. According to Haq, von Rad, O'Connell, et al. (1990, pp. 511 and 520), this unit was assigned a questionable Neocomian age (Cores 122-761 B-30X-1, 0 cm, to $-31 \mathrm{X}-1,0 \mathrm{~cm}$ ) and a Tithonianlower Valanginian age (Cores $122-761 \mathrm{~B}-1 \mathrm{OR}-1,40 \mathrm{~cm}$, to $-761 \mathrm{C}$ $11 \mathrm{R}-1,0 \mathrm{~cm})$. The unit is underlain by a pale limestone of Rhaetian age (Haq, von Rad, O'Connell, et al., 1990). Two belemnite fragments from Section 122-761B-30X-2 were examined. This core was assigned a questionable Neocomian age because microfossils are absent.

Hole $762 \mathrm{C}\left(19^{\circ} 53.23^{\prime} \mathrm{S}, 112^{\circ} 15.24^{\prime} \mathrm{E}\right.$; water depth $\left.=1360 \mathrm{~m}\right)$ was drilled in the western part of the central Exmouth Plateau, about $300 \mathrm{~km}$ southwest of Site 761 . Here, black shales of early Aptian age (based on nannofossil and palynomorph biomarkers) are underlain by black to very dark gray claystones of Berriasian

\footnotetext{
${ }^{1}$ Gradstein, F. M., Ludden, J. N., et al., 1992. Proc. ODP, Sci. Results, 123: College Station, TX (Ocean Drilling Program).

Department of Geology, University of Nebraska, Lincoln, NE 68588, U.S.A. (current address: Institut für Geologie und Paläontologie, Universität Hannover, Callinstr. 30, 3000 Hannover 1, Federal Republic of Germany).
}

to early Valanginian age (lithologic Unit VI; Haq, von Rad, O'Connell, et al., 1990:638). Cores 122-762C-81X-1, $0 \mathrm{~cm}$, to $-91 \mathrm{X}-\mathrm{CC}$ were assigned a Berriasian to early Valanginian age on the basis of palynomorphs. In the upper part of Unit VI (Core $122-762 \mathrm{C}-81 \mathrm{X}$ ) belemnite guards are common, although they also are present in the lower part of Unit VI. Three belemnite fragments from Sections 122-762C-81X-1, $-81 X-2$, and $-81 X-3$ were studied. These sections are of early Valanginian age (Batioladinium reticulatum to Egmontodinium torynum Zone) according to the palynomorphs (Haq, von Rad, O'Connell, et al., 1990, p. 245). Holes 763B and $763 \mathrm{C}\left(20^{\circ} 35.19^{\prime} \mathrm{S}, 112^{\circ} 12.52^{\prime} \mathrm{E}\right.$; water depth $=$ $1367.50 \mathrm{~m}$; and $20^{\circ} 35.21^{\prime} \mathrm{S}, 112^{\circ} 12.51^{\prime} \mathrm{E}$; water depth $=1367.50$ $\mathrm{m})$ are located about $84 \mathrm{~km}$ south of Site 762 on the western part of the central Exmouth Plateau. Below a black silty claystone (Unit V) of early Aptian age (based on calcareous nannofossils and palynomorphs), dark gray clayey siltstones of shelf margin prodelta origin were cored (Units VI, VII). These were assigned a Berriasian to Valanginian age (Haq, von Rad, O'Connell, et al., 1990), based on calcareous nannofossils and palynomorphs.

Cores $122-763 \mathrm{~B}-48 \mathrm{X}-1$ to $-54 \mathrm{X}-\mathrm{CC}$ (Unit VI) have a Berriasian to early Valanginian age, based on calcareous nannofossils and palynomorphs. Belemnites are present throughout the sequence. Three belemnite fragments from Sections 122-763C13R-5, -25R-5, and -35R-5 were examined. These sections are of middle to late Berriasian age (Dissimulidinium lobispinosum to Batioladinium reticulatum Zone).

Hole $766 \mathrm{~A}\left(19^{\circ} 55.985^{\prime} \mathrm{S}, 110^{\circ} 27.130^{\prime} \mathrm{E}\right.$; water depth $=4008$ $\mathrm{m})$ was drilled at the boundary between the Cuvier and Gascoyne abyssal plains about $225 \mathrm{~km}$ northwest of Site 763 . Of the $460 \mathrm{~m}$ of sediments encountered in this hole, about $300 \mathrm{~m}$ (Cores 123766A-48R to -18R) were assigned an Early Cretaceous age (latest Valanginian to Albian, based on calcareous nannofossils). The upper Valanginian to Barremian is represented by dark glauconitic sandstones and siltstones (lithologic Subunit IIIB), Cores 123-766A-28R-6 to -50R-1 (Ludden, Gradstein, et al., 1990).

One belemnite fragment from Section 123-766A-42R-2, which is of Hauterivian age (Cruciellipsis cuvillieri Zone, according to the calcareous nannofossils), was studied.

\section{BELEMNITE FAUNAS}

The order Belemnitida is interpreted here in the sense of Jeletzky (1966). Jeletzky (1966) recognized three suborders: (1) Belemnitina, characterized by one or more apical furrows; (2) Belemnopseina, having alveolar grooves; and (3) Diplobelina, a 


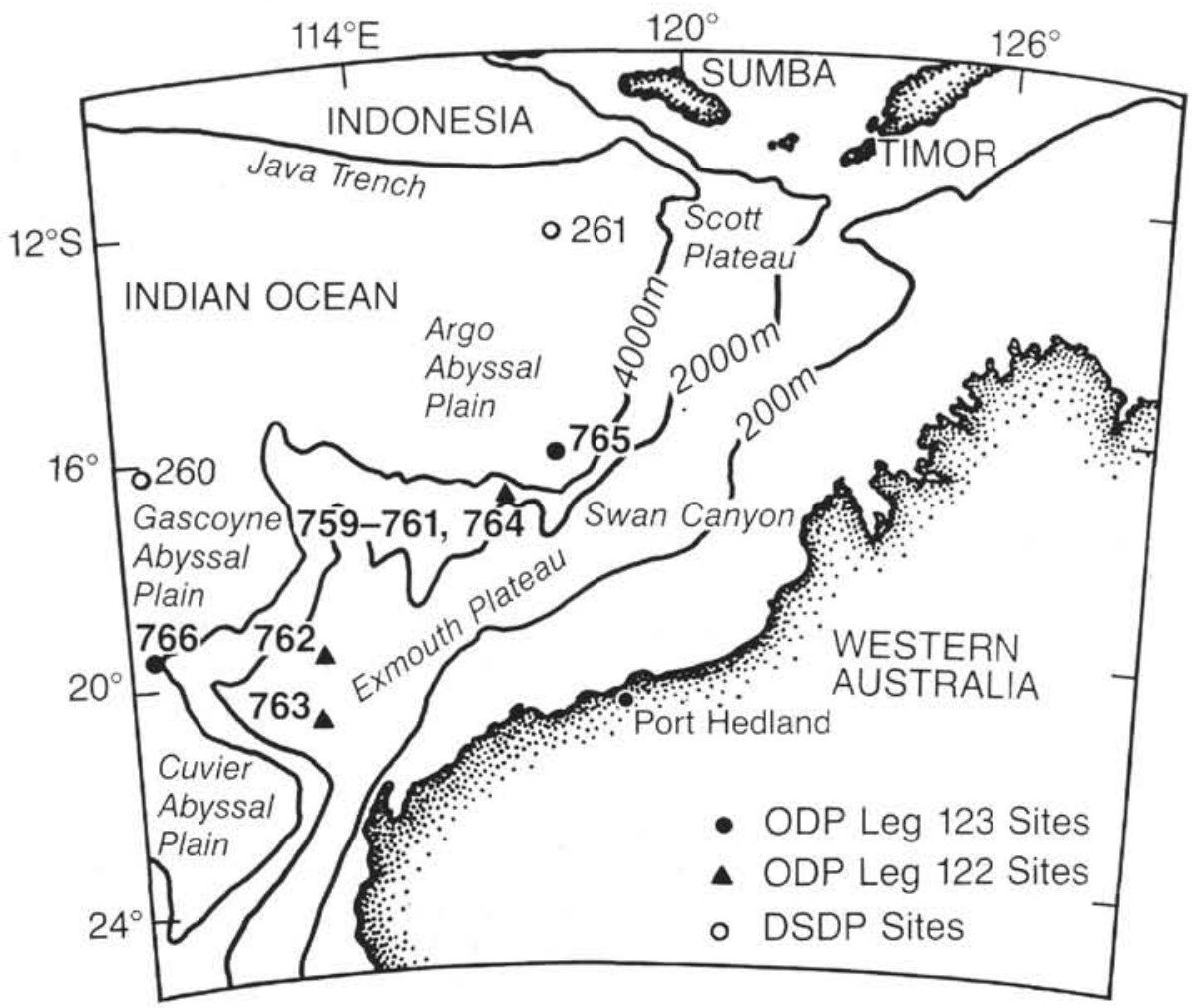

Figure 1. Location of Sites 761, 762, 763, and 766.

group of small forms having much reduced guards. All specimens considered here are included in the suborder Belemnopseina (Fig. 2). For an explanation of specific terms (e.g., stem region) used here, refer to Stevens (1965b) and Combemorel (1988).

\section{SYSTEMATIC DESCRIPTIONS}

Class CEPHALOPODA Cuvier, 1797

Subclass COLEOIDEA Bather, 1886

Order BELEMNITIDA Zittel, 1895

Suborder BELEMNOPSEINA Jeletzky, 1965

Family BELEMNOPSEIDAE Naef, 1922

Genus BELEMNOPSIS Bayle and Zeiller, 1878

Type species. Belemnites bessinus d'Orbigny, 1842.

Diagnosis. The elongate guard is often cylindrical, sometimes hastate or subhastate. A prominent, broad, deep, median ventral groove extends from the alveolar region almost to the apex. The apical line is ventrally placed.

Comparison. The genus Hibolithes, which resembles that of Belemnopsis in some aspects, differs by its pronounced hastate guard and its shorter, less prominent, ventral groove. The latter is often restricted to the alveolar region

Remarks. The genus Belemnopsis includes a variety of forms that range in shape from elongate-cylindrical and stout-cylindrical to strongly elongate-hastate. A major problem when defining species is that Belemnopsis occurs in the Indo-Pacific and in the Mediterranean provinces of the Tethyan Realm. Geographic isolation of Belemnopsis in the IndoPacific Province resulted in the evolution of several endemic stocks, which are partly homeomorph.

Distribution. Belemnopsis ranges from the Lower Jurassic (Toarcian) to the Hauterivian. In the Mediterranean Province (central and southern Europe, north Africa), where Belemnopsis originated, age ranges from the Toarcian to the Oxfordian. In the Indo-Pacific Province (India, Madagascar, South America, Antarctica, New Zealand, Australia, Indonesia), the species is known from the Bathonian to the Hauterivian.
Belemnopsis cf. jonkeri Stolley, 1929

(Pl. 1, Figs. 1-3, 5)

pars 1929 Belemnopsis jonkeri Stolley; p. 176, Pl. 5, Figs. 1-11; Pl. 4, Fig. 11.

Material. Four fragments (Cores 122-761B-30X-2, 11-12 cm; -761B$30 X-2,18-19 \mathrm{~cm} ;-763 \mathrm{~B}-50 \mathrm{X}-4,115 \mathrm{~cm} ;-763 \mathrm{C}-25 \mathrm{R}-5,108 \mathrm{~cm})$ from the Wombat and Exmouth plateaus.

Description. All four guards are incomplete. The apical and alveolar regions are missing in all four specimens. As the protoconch has not been preserved, the fragments represent only the stem region of the belemnite guard. The elongate specimens are characterized by a deep, and wide, median ventral groove that extends all over the guards. In all four specimens, the lateral diameter slightly exceeds that of the dorsoventral. The ratio (dorsoventral diameter/lateral diameter) varies between 0.93 and 0.98 , indicating that the cross section of the stem region is always depressed. One juvenile specimen (Sample 122-763C-25R-5, $108 \mathrm{~cm}$ ) shows an increase of the lateral diameter in an adapical direction. This indicates a slightly hastate shape, with a maximum diameter situated in the stem region.

Remarks. Several Belemnopsis species, which appear to resemble the specimens from Holes 761B, 763B, and 763C, have been described from the Upper Jurassic of Indonesia (Boehm, 1907a, 1907b; Kruizinga, 1921; Stolley, 1929, 1935; Stevens, 1965a; Challinor and Skwarko, 1982), New Zealand (Stevens, 1965b), the Falkland Plateau (Jeletzky, 1983), Madagascar (Besairie, 1932, 1936; Combemorel, 1988), and India (Spath, 1927, 1934, 1939; Stevens, 1963). Most of the species from Indonesia have been revised recently and coalesced by Challinor (1989). This concept is followed here.

Comparison. The Indonesian species Belemnopsis galoi Boehm, 1907, Belemnopsis stolleyi Stevens, 1964, and Belemnopsis jonkeri Stolley, 1929 are all similar to the material from Holes 761B and 763C. B. cf. jonkeri differs from B. galoi (of Tithonian age; Challinor, 1989) by its stratigraphic position and its more elongate outline.

B. stolleyi has a circular cross section (Challinor, 1989, Fig. 7); B. cf. jonkeri, however, has a depressed cross section. The value for the ratio 
A (lateral diameter/dorsoventral diameter) varies between 1.04 and 1.06 for $B$. cf. jonkeri. This species has a wider and shallower ventral groove than $B$. stolleyi. The stratigraphic position of the belemnite guards discussed here (Berriasian to Valanginian) supports this determination because B. stolleyi is known only from the late Tithonian (Challinor, 1990).

$B$. cf. jonkeri differs from Belemnopsis aucklandica (Hochstetter, 1863 ) by its wider groove and its more elongate guard and from Belemnopsis keari (Stevens, 1965) by its stratigraphic position. The latter two species have been described from New Zealand,

Distribution. B. jonkeri was described by Stolley (1929) from the Kimmeridgian of Indonesia. However, according to Challinor (1989), in Indonesia it ranges from the late Tithonian to the Neocomian. This species has not been reported elsewhere. Based on the associated nannofossils, the two belemnite fragments from Section 122-761B-30X-2 were assigned a questionable Neocomian age as microfossils are absent. The specimen from Sample 122-763B-50X-4, $115 \mathrm{~cm}$, has a Berriasian to early Valanginian age (based on calcareous nannofossils and palynomorphs). The guard from Section 122-763C-25R-5 is of middle to late Berriasian age (Dissimulidinium lobispinosum to Batioladinium reticulatum Zone).

Belemnopsis ex. gr. moluccana s.1. (Boehm, 1907)

$$
\text { (Pl. 1, Fig. 4) }
$$

Material. One specimen $(122-763 \mathrm{C}-13 \mathrm{R}-5,27-28 \mathrm{~cm})$ from the Exmouth Plateau.

Description. Fragment of the stem region of a juvenile specimen. Neither the alveolar region nor the stem region has been preserved. A deep, wide, ventral groove has developed along the length of the stem region. The cross section is slightly depressed.

Comparison. It is virtually impossible to differentiate between isolated juvenile specimens of the B. moluccana lineage described by Challinor (1989), which here is understood to include $B$. jonkeri. The early ontogenetic stages of B. moluccana Boehm, 1907, B. galoi, B. stolleyi, and $B$. jonkeri are morphologically similar and exhibit a hastate shape. Thus, the specimen described here is a member of the $B$. moluccana Group s. 1 , including $B$. jonkeri,

Distribution. Based on the palynomorphs, the specimen has a late Berriasian age (Dissimulidinium lobispinosum to Batioladinium reticulatum Zone).

\section{Genus HIBOLITHES Montfort, 1808}

Type species. Hibolithes hastatus Montfort, 1808.

Diagnosis. Guard elongate and slender, normally club-shaped. A median ventral groove, often confined to the alveolar region, occasionally extends onto the stem region. The apical line is ortholineate.

Comparison. The guards of Mesohibolites are stouter and more conical in shape, and have a long median groove. Neohibolites differs by having a short groove and a less-elongated guard.

Remarks. The genus Hibolithes includes a wide range of forms that vary in shape from elongate-cylindrical to stout, strongly hastate. The length of the central groove varies. During the Early Cretaceous, Hibolithes occurred in the Indo-Pacific and Tethyan provinces, as well as in the Boreal Realm. Allopatric speciation of Hibolithes in these regions resulted in the evolution of endemic species and at any given time, homeorphic forms developed independently within the three regions.

Distribution. Hibolithes ranges from the Middle Jurassic (Bajocian) to the lower Aptian in northwest Europe and to the Albian in Papua New Guinea (Challinor, 1990). Its known geographical distribution is as follows: Middle Jurassic of central and southern Europe and New Zealand; Upper Jurassic of central and southern Europe, India, Madagascar, South America, Antarctica, New Zealand, and Indonesia; Lower Cretaceous of central and southern Europe, northern Europe, North America, Madagascar, Australia, Indonesia, and Papua New Guinea.

\section{(?)Hibolithes sp.}

Material. One specimen (Sample 122-763B-48X-3, 48-49 cm.) from the Wombat Plateau.

Description. The specimen lacks the alveolar and the apical regions. The guard is elongate and slender and has a symmetrical and slightly hastate outline (ventral view). A shallow and narrow ventral groove has developed all along the alveolar region and extends well onto the stem region. The cross section is slightly compressed laterally.
Remarks. Species similar to (?)Hibolithes sp. have been described from the Upper Jurassic of Indonesia (Boehm, 1907a, 1907b; Stolley, 1929,1935 ) and New Zealand (Stevens, 1965b). However, the species described from Madagascar by Combemorel (1988) are different and resemble the $H$. subfusiformis type.

Comparison. (?)Hibolithes sp. is similar to Hibolithes arkelli Stevens, 1965 and Hibolithes marwicki Stevens, 1965; both species have been described from the lower and middle Tithonian of New Zealand. It differs from $H$. arkelli by its less-compressed guard and its less-pronounced ventral groove. $H$. marwicki has a more slender and elongate guard. Hibolithes australis Challinor, 1990, which occurs in the late Tithonian of Indonesia and Papua New Guinea, differs from (?)Hibolithes sp. by having a shorter ventral groove and an almost circular cross section. Hibolithes gamtaensis Challinor, 1990, described from the Hauterivian of Indonesia and Papua New Guinea by Challinor (1990), differs from (?)Hibolithes sp. by its depressed cross section.

Distribution. In the absence of data to describe the Neocomian Hibolithes assemblages of the Indo-Pacific area, no stratigraphic or geographic information can be given. Based on the associated palynomorphs, this specimen has an early Valanginian age (Egmontodinium torynum Zone).

\section{Family DUVALIIDAE Pavlow, 1914 Genus DUVALIA Bayle, 1878}

Type species. Belemnites latus Blainville, 1827.

Diagnosis. Markedly compressed, slightly hastate to rodlike guards, with a more or less inflated ventral surface. A median dorsal groove is developed.

Comparison. Duvalia differs from Produvalia by its more inflated ventral surface and by its stratigraphic position.

Distribution. Duvalia is known from the Tithonian to the lower Aptian in the Mediterranean Province and from the Tithonian to the upper Aptian in the Indo-Pacific Province. A stratigraphically isolated species was described by Combemorel (1988) from the Turonian of Madagascar. In the Boreal Realm, Duvalia is known only from the middle Aptian.

\section{Duvalia cf. sakalava Besairie, 1930}

$$
\text { (Pl. 1, Fig. 7) }
$$

Material. One specimen (Sample 123-766A-42R-2, 41-43 cm) from the Gascoyne Abyssal Plain.

Description. The small guard is strongly compressed, and the maximum lateral diameter lies in the stem region near the apex. The dorsal outline is symmetrical and slightly hastate. In profile, the ventral surface is more inflated than the dorsal surface. A dorsal groove is not preserved.

Comparison. Duvalia cf. sakalava is similar to Duvalia silesiaca Uhlig, 1901, from which it differs by its less-pronounced ventral inflation.

Distribution. In the Indo-Pacific Province, Duvalia has been described in detail only from the Bathonian-Aptian of Madagascar (Combemorel, 1988). Other species have been mentioned from India and Indonesia (Stolley, 1929, 1935; Challinor, pers. comm., 1990). However, no detailed data are available for the latter two areas. Judging from the associated calcareous nannofossils, the specimen of Duvalia $\mathrm{cf}$. sakalava from the Gascoyne Abyssal Plain has a Hauterivian age.

\section{PRESERVATION}

Because of drilling, none of the belemnite guards discussed is complete. All of the specimens represent the stem region, with both apex and alveolar regions missing. Other parts consist of the apex only, without the stem and alveolar regions.

As expected, considering the lithology, two different ways of preserving the guards were noted. First, the specimens that were embedded in claystones and silty claystones are well preserved. Their surfaces show no signs of corrosion from migrating pore waters. These specimens are represented by the material derived from Holes 763B, 763C, and 766A. A few specimens, which were split dorsoventrally along the de Klähnsche Grenzfläche, showed intensive corrosion. Second, the specimens embedded in sandstones have been strongly corroded by the effect of circulating undersaturated pore waters. Typically, these highly corroded guards reveal a porous surface. In some specimens, the intensive 
diagenetic dissolution has even affected the anterior end of the guard. In these specimens, the alveolar region (including the phragmocone) has not been preserved. As a result of heavy corrosion, the apical line has been transformed into a small open tube. This tube, because of secondary effects, has no biological function. It was caused by the orientation of the calcite crystals along the apical line. The calcite prisms, which are arranged radially throughout most of the guard, change at the apex into an orientation parallel to the long axis. This creates a zone of weakness and reduced stability around the apical line (Spaeth, 1971, p. 24). This "pseudo-apical channel" offers a good opportunity for replacement or permineralization of the shell. Specimens from this type of highly corrosive environment are represented by the material derived from Hole $761 \mathrm{C}$.

\section{HOMEOMORPHIES IN BELEMNITES}

The belemnite guard, an internal skeleton composed of solid calcite, presumably served two functions: (1) as a counterweight to the chambered phragmocone and (2) as a means of protection. Because the overall morphology is simple, only a few features have been used for taxonomic purposes. These include measurable values (e.g., the overall length, the dorsoventral diameter, the lateral diameter) and relative characteristics (grooves, lateral lines). All these features have been used widely in recent years by many scientists (e.g., Stevens, 1965; Christensen, 1974) to describe different species. As these characteristics are limited in scope, convergence is to be expected. In particular, some morphological trends are repeated over and over again, as follows:

1. The development from hastate to conical forms and vice versa.

2. The change of the cross section from round to oval and vice versa.

It is apparent that major features, such as the ventral groove, had little permanence of character. For example, the Oxyteuthinae (common in the Barremian of northwest Europe) form an evolutionary lineage that consists of three genera: Praeoxyteuthis-Aulacoteuthis-Oxyteuthis (Mutterlose, 1983, 1990). The early species of Aulacoteuthis are characterized by the development of a deep ventral groove and the late species, by a reduction of the groove. Both ancestors (Praeoxyteuthis) and descendants (Oxyteuthis) of the Aulacoteuthis lineage lack grooves. The Aulacoteuthis lineage has been restricted to the upper part of the lower Barremian and represents a period of probably less than $0.5 \mathrm{~m} . \mathrm{y}$. Consequently, homeomorphic groups and species are to be expected for all belemnites. In particular, convergent evolution is even more likely for Belemnopsis and Hibolithes for two reasons: (1) both are long-ranging genera; Belemnopsis ranges from the Toarcian to the Hauterivian; Hibolithes, from the Bathonian to the Aptian; and (2) both Belemnopsis and Hibolithes are geographically widespread genera, common in the Boreal Realm, the Mediterranean Province. and the Indo-Pacific Province. These groups have a tendency to evolve in geographically isolated populations endemically.

Allopatric speciation of geographically isolated forms is most likely to occur in these genera, giving way repeatedly to endemic homeomorphic groups. Figure 2 presents the stratigraphic distribution of the various Belemnsis stocks in the Indo-Pacific Province.

\section{PALEOBIOGEOGRAPHY AND MIGRATION}

Two separate faunal realms during the Late Jurassic and Early Cretaceous can be distinguished that are characterized by different belemnite assemblages (Figs. 3 and 4). For the Oxfordian to Barremian stages, these comprise the Tethyan and the Boreal realms. The Tethyan Realm (southern and central Europe, eastern Africa, Madagascar, Antarctica, South America, New Zealand, Indonesia, Australia, and India) was characterized by the Belelmnopseidae, Duvalidae, and Dicoelitidae. Within the Tethyan Realm, two different belemnite provinces may be distinguished from the Kimmeridgian onward (e.g., Stevens, 1963, 1965b, 1973a, 1973b; Combemorel, 1988; Mutterlose, 1988; Dole and Howlett, 1989):

1. The Mediterranean Province (southern Germany, the Alps, France, Spain, Morocco, Sicily, Crimea, and Bulgaria) without Belemnopsis.

2. The Indo-Pacific Province s.l. (eastern Africa, India, Australia, Indonesia, New Zealand, and Antarctica), dominated by endemic Belemnopsis.

Belemnopsis, which originated in the Toarcian of the Mediterranean Province, is unknown from this area from the Kimmeridgian onward. However, in the Indo-Pacific Province, Belemnopsis appeared first in the Bathonian and persisted into the Hauterivian. By contrast, Hibolithes is common in both provinces throughout the Late Jurassic and continued to the Barremian.

Because of the geographic isolation of Belemnopsis and Hibolithes in the Indo-Pacific Province (Stevens, 1963, 1965a, 1973a, 1973b; Combemorel, 1988), a regional differentiation is possible for the Late Jurassic (Fig. 3):

1. Madagascar, Ethiopia, and Somaliland are characterized by the Belemnopsis madagascariensis-B. castarensis Group (Combemorel, 1988). This group characterizes the Ethiopian Subprovince.

2. India, Indonesia, New Zealand, Antarctica, and South America are dominated by the Belemnopsis aucklandica-B. uhligi Group (Stevens, 1965b), which defines the Indo-Pacific Subprovince.

The Belemnopsis moluccana-B. stolleyi Group, which is common in Indonesia (Challinor, 1989), is here included in the IndoPacific Subprovince because this lineage exhibits similarities to the $B$. aucklandica-B. uhligi Group.

This situation changed considerably during the Early Cretaceous (Fig. 4). During the Berriasian-Hauterivian, a faunal migration took place between the Ethiopian Subprovince and Antarctica-Patagonia. Thus, typical species from Madagascar are known to occur from Antarctica (Howlett, 1989). The Belemnopsis species (known from Indonesia and Sites 761 through 766) are different from the Ethiopian and Antarctic belemnite faunas. Thus, two subprovinces have been recognized for the Early Cretaceous (Berriasian-Hauterivian; Fig. 4), as follows:

1. Madagascar, Ethiopia, Somaliland, South America, and Antarctica are characterized by the Belemnopsis madagascariensis-B. castarensis Group and by Belemnopsis gladiatoris Wiley, 1973 (Combemorel, 1988; Doyle and Howlett, 1989). Here, this region is referred to as the Ethiopian-Antarctic Subprovince.

2. Indonesia and northwest Australia (Legs 122 and 123) exhibit different Belemnopsis species (Belemnopsis ex gr. jonkeri) that constitute an Indonesian Subprovince.

The belemnites recovered during Leg 122 exhibit close affinities with the material described from Indonesia. Thus, I consider the belemnite faunas of northwest Australia to have been a part of the Indonesian Subprovince during the Early Cretaceous. However, note that this opinion is based on comparatively few (not detailed) data. In contrast, these changes (in terms of provinciality) fit well into the established plate-tectonic framework. The 


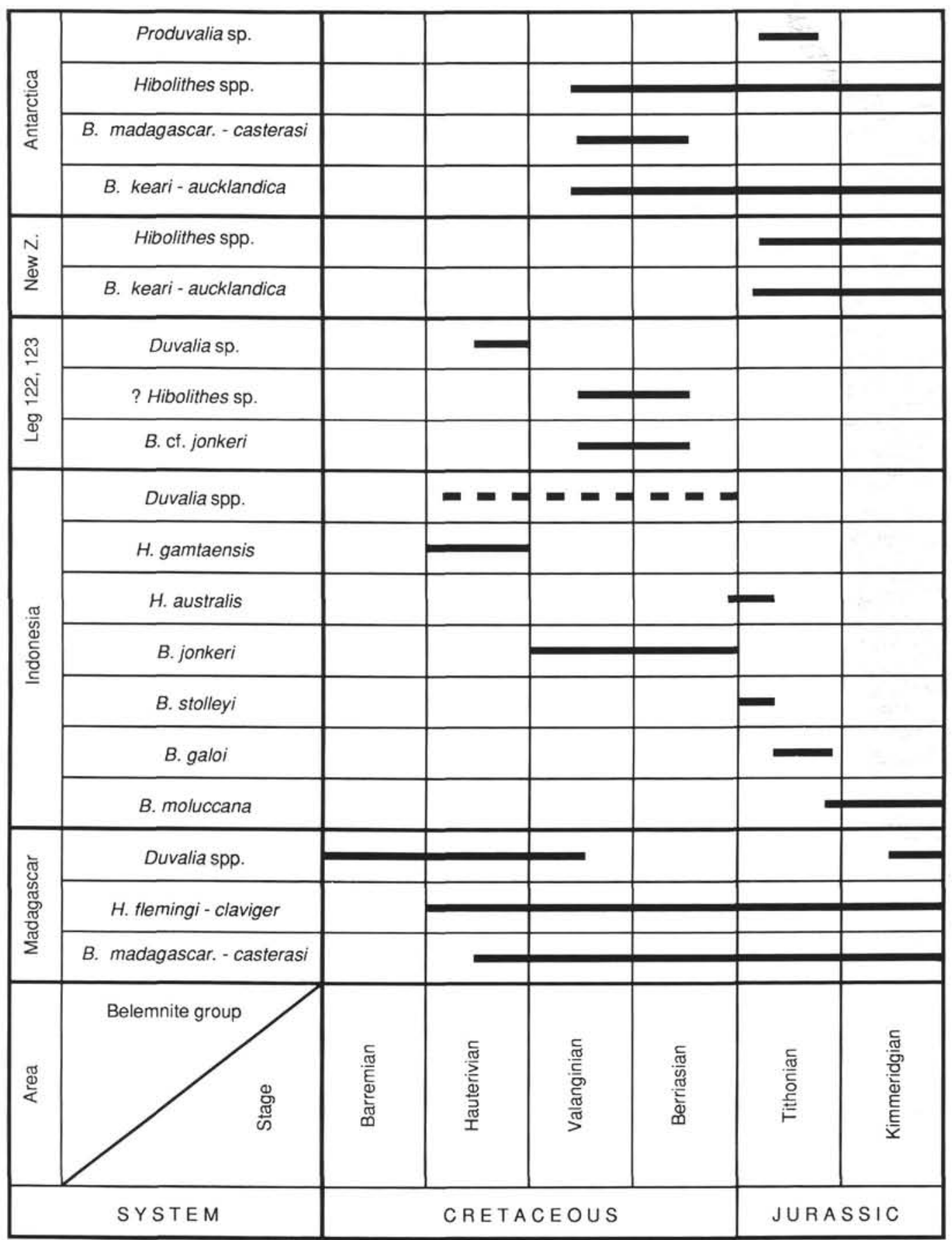

Figure 2. Range chart for various belemnite groups in the Indo-Pacific Province of the suborder Belemnopseina. Compiled from numerous sources (see text). B. = Belemnopsis; $H$. = Hibolithes. Duvalia sp. in the column Leg 122 , 123 represents Duvalia cf. sakalava. For Madagascar, New Zealand and Antarctica are the only stock groups listed; these also include other species. Ranges are listed only for those areas of the Indo-Pacific Province from which detailed data are available.

rifting between Australia and India, which began during the Early Cretaceous, caused increased isolation of northwest Australia and Indonesia and permitted the evolution of new species from allopatric speciation.

While the described forms of Belemnopsis and Hibolithes are endemic to the Indonesian Subprovince, the occurrence of $\mathrm{Du}$ valia is more difficult to interpret. In the Mediterranean Province,
Duvalia is common throughout the Tithonian-lower Aptian. Recently, Combemorel (1988) described Duvalia from the Lower Cretaceous of the Indo-Pacific Province (Madagascar), where it is common. According to Challinor (pers. comm., 1990), Duvalia also is common in the Lower Cretaceous (Berriasian-Hauterivian) of Misool (Indonesia). However, no published data are available. 


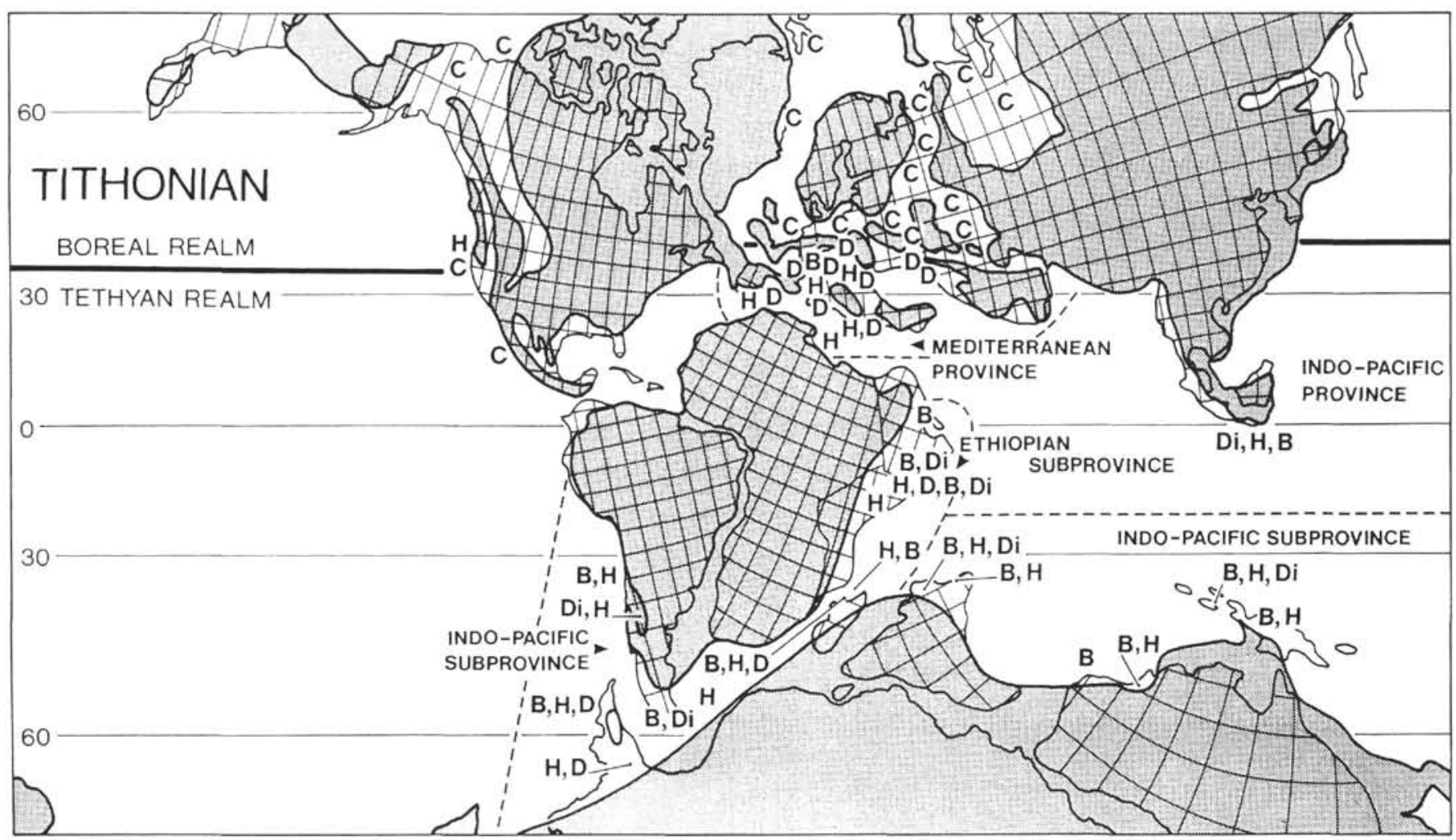

Figure 3. Paleobiogeography of belemnites from the Late Jurassic (Kimmeridgian, Tithonian). Plate tectonics after Barron et al. (1981). Belemnite assemblages based on various sources (see text). $\mathrm{B}=$ Belemnopsis, $\mathrm{C}=$ Cyclindroteuthididae, $\mathrm{D}=$ Duvalia $, \mathrm{Di}=\mathrm{Dicoelitidac}, \mathrm{H}=$ Hibolithes .

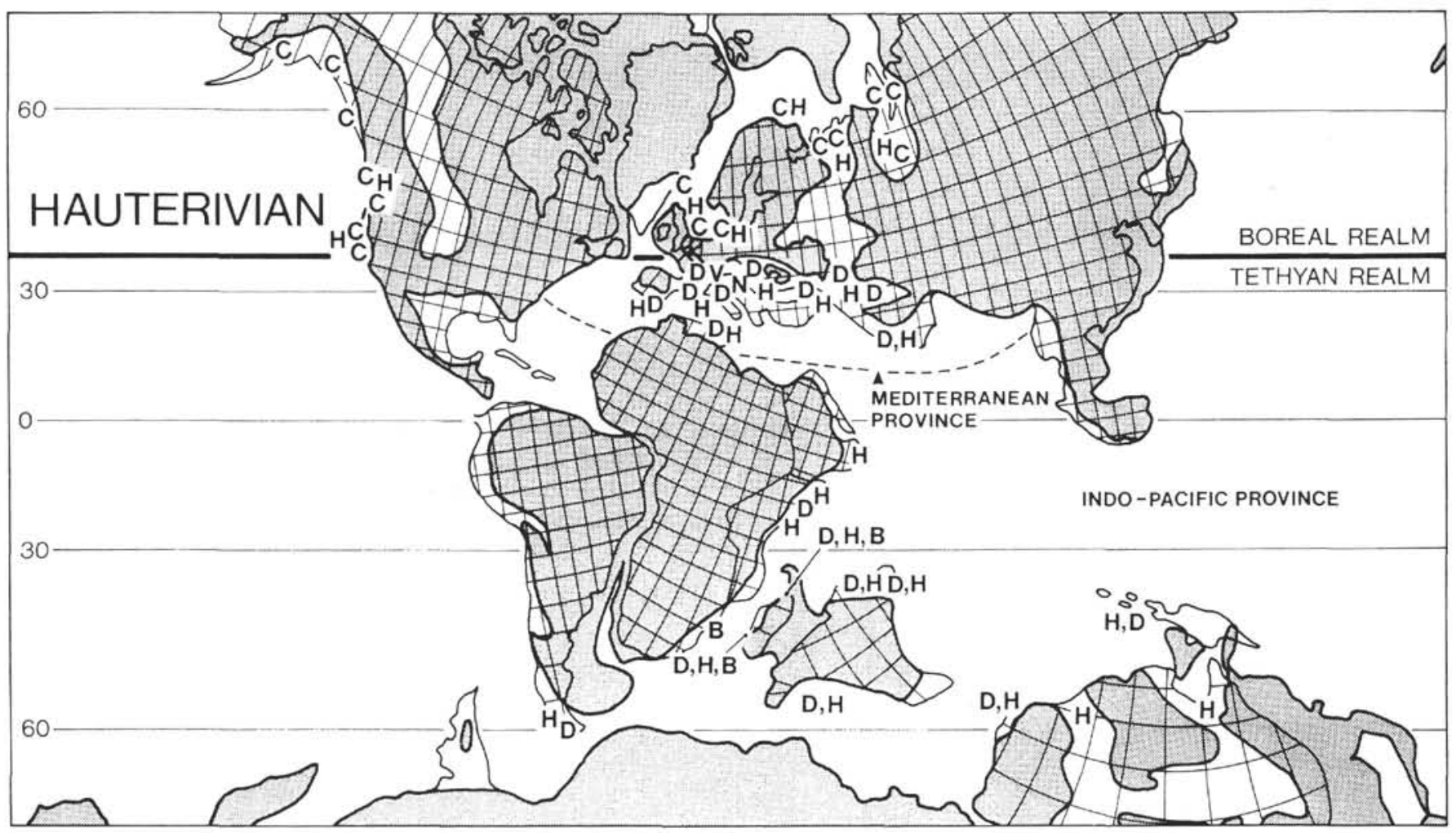

Figure 4. Paleobiogeography of belemnites from the Early Cretaceous (Berriasian-Barremian). Plate tectonics after Barron et al. (1981). Belemnite assemblages based on various sources (see text). $\mathrm{B}=$ Belemnopsis, $\mathrm{C}=$ Cylindroteuthididae, $\mathrm{D}=$ Duvalia , and $\mathrm{H}=$ Hibolithes . 


\section{ACKNOWLEDGMENTS}

I am grateful to C. Spaeth (University of Hamburg, F.R.G.), G. Stevens (Geological Survey of New Zealand), and J. Wiedmann (University of Tübingen, F.R.G.) for critical reviews and for useful suggestions. I wish to thank U. von Rad (BGR, Hannover) for discussions and B. Challinor (Hamilton, New Zealand) for important information about the Indonesian belemnite faunas. Janalisa Soltis provided helpful editorial comments.

\section{REFERENCES}

Barron, E. J., Harrison, C.G.A., Sloan, J. L., II, Hay, W. W., 1981. Paleogeography, 180 million years ago to the present. Eclogae Geol. Helv., 74:443-470.

Besairie, H., 1932. Fossil caractéristiques du nord et du nord-ouest de Madagascar. Ann. Geol. Serv. Mines (Madagascar), 2:37-53.

1936. Recherches géologiques à Madagscar. Mem. Acad. Malgache, 21:145-148.

Boehm, G., 1907a. Beiträge zur Geologie von Niederländisch-Indien. 1: Die Südküsten der Sula-Inseln Taliabu und Mangoli. 2: Der Fundpunkt am Oberen Lagoi auf Taliabu. Palaeontographica Suppl.. 4:4758.

1907b. Beiträge zur Geologie von Niederländisch-Indien. 1: Die Südküsten der Sula-Inseln Taliabu und Mangoli. 3: Oxford des Wai Galo. Palaeontographica Suppl., 4:61-120.

Challinor, A. B., 1989. The succession of Belemnopsis in the Late Jurassic of eastern Indonesia. Palaeontology, 32:571-596.

1990. A belemnite zonation for the Jurassic- Cretaceous of Papua New Guinea and a faunal comparison with eastern Indonesia. BMR J. Aust. Geol. Geophys., 11:429-447.

Challinor, A. B., and Skwarko, S. K., 1982. Jurassic belemnites from Sula Islands, Moluccas, Indonesia. Geol. Res. Dev. Cent. Pal. Bull., 3 : $1-89$.

Christensen, W. K., 1974. Morphometric analysis of Actinocamax plenus from England. Bull. Geol. Soc, Den., 23:1-26.

Combémorel, R., 1973. Les Duvaliidae Pavlow (Belemnitida) du Crétace inférieur Français. Doc. Lab. Geol. Lyon, 57:131-185. 1988. Les belemnites de Madagascar. Doc. Lab. Geol. Lyon, 104:1-239.

Doyle, P., and Howlett, P., 1989. Antarctic belemnite biogeography and the break-up of Gondwana. In Crame, J. A. (Ed.), Origins and Evolution of the Antarctic Biota. Geol. Soc. Spec. Publ., 47:167-12.

Haq, B. U., von Rad, U., O'Connell, S., et al., 1990. Proc. ODP, Init. Repts., 122: College Station, TX (Ocean Drilling Program).

Howlett, P., 1989. Late Jurassic-Early Cretaceous cephalopods of eastern Alexander Island, Antarctica. Spec. Pap. Pal., 41:1-72.

Jeletzky, J. A., 1966. Comparative morphology, phylogeny and classification of fossil coleoidea. Univ. Kansas Paleontol. Contrib., Mollusca, 7:1-162.
1983. Macroinvertebrate paleontology, biochronology and paleoenvironments of Lower Cretaceous and Upper Jurassic rocks, Deep Sea Drilling Project Hole 511, East Falkland Plateau. In Ludwig. W. J., Krasheninnikov, V. A., et al., Init. Repts. DSDP. 71: Washington (U.S. Govt. Printing Office), 951-975.

Kruizinga, P., 1921. De Belemnieten uit de jurassischen afzettingen van de Soela-Eilanden. Jaarb. Mijn. Ned. Oost-Indie, 49:161-189.

Ludden, J. N., Gradstein, F. M., et al., 1990. Proc. ODP, Init. Repts., 123: College Station, TX (Ocean Drilling Program).

Mutterlose, J., 1983. Phylogenie und Biostratigraphie der Unterfamilie Oxyteuthinae (Belemnitida) aus dem Barreme (Unter-Kreide) NWEuropas. Palaeontographica A, 180:1-90.

1988. Migration and evolution patterns in Upper Jurassic and Lower Cretaceous Belemnites. In Wiedmann, J., and Kullmann, J. (Eds.), Cephalopods-Present and Past: Stuttgart (Schweizerbart), 525-537.

1990. A belemnite scale for the Lower Cretaceous. Cretaceous Res., 11:1-15.

Spaeth, C., 1971. Untersuchungen an Belemniten des Formenkreises um Neohibolites minimus (MILLER 1826) aus dem Mittel- und Ober-Alb Nordwestdeutschlands. Geol. Jahrb. Beih., 100:1-127.

Spath, L. F., 1927. Revision of the Jurassic cephalopod fauna of Kachh (Cutch). Mem. Geol. Surv. India, Palaeontologica Indica, N.S., 9:171.

1934. The Jurassic and Cretaceous ammonites and belemnites of the Attock District. Mem. Geol. Surv. India, Paläontologica Indica. N.S., 20:1-39.

1939. The Cephalopoda of the Neocomian belemnite beds of the Salt Range. Mem. Geol. Surv. India, Palaeontologica Indica, N.S., 25: 1-154

Stevens, G. R., 1963. Faunal realms in Jurassic and Cretaceous belemnites. Geol. Mag., 100:481-497.

1965a. A new belemnite from the Upper Jurassic of Indonesia. Palaeontology, 7:621-629.

, 1965b. The Jurassic and Cretaceous belemnites of New Zealand and a review of the Jurassic and Cretaceous belemnites of the IndoPacific Region. N. Z. Geol. Surv., Paleontol. Bull., 36:1-283.

1973a. Jurassic belemnites. In Hallam, A. (Ed.), Atlas of Paleo biogeography: Amsterdam (Elsevier), 259-274.

1973b. Cretaceous belemnites. In Hallam, A. (Ed.), Atlas of Palaeobiogeography: Amsterdam (Elsevier), 385-401.

Stolley, E., 1929. Über Ostindische Jura-Belemniten. Paläontol. Timor., Lief. 16, Abh. 29:91-213.

1935. Zur Kenntnis des Jura und der Unterkreide von Misol. Paläontologischer Teil. Neues Jahrb. Mineral. Geol. Paläontol., Abt. B, 73:42-69.

Date of initial receipt: 27 June 1990

Date of acceptance: 8 January 1991

Ms 123B-123 


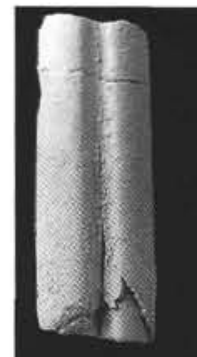

1
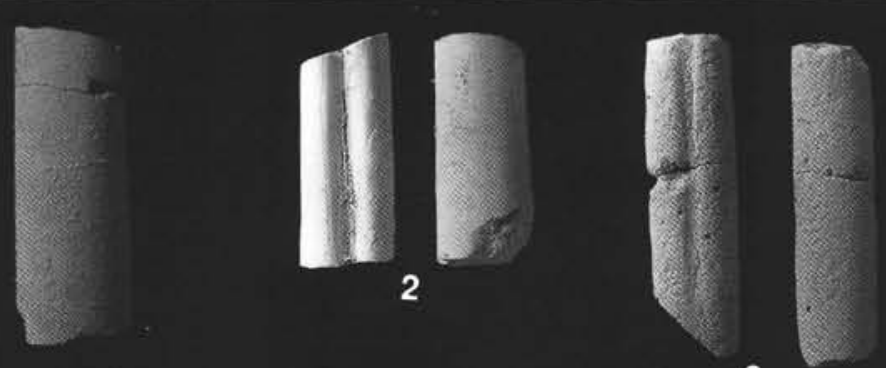

3

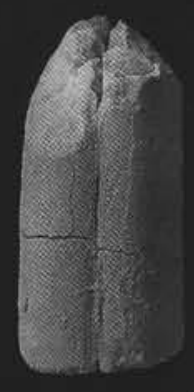

6
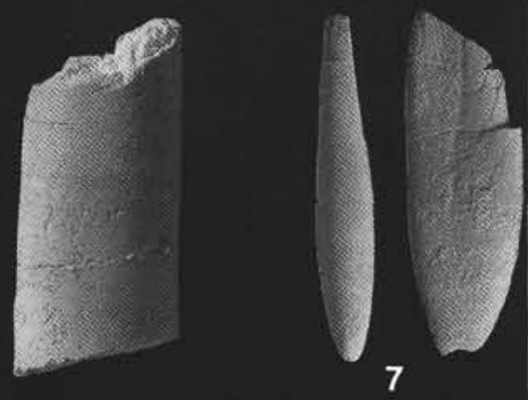

5

Plate 1. 1-3, 5. Belemnopsis cf. jonkeri Stolley, 1929; (1) Sample 122-761B-30X-2, 18-19cm, (?)Berriasian-Valanginian; (2) Sample 122-763C-25R-5, $108 \mathrm{~cm}$, middle to upper Berriasian (D. lobispinosum to B. reticulatum Zone); (3) Sample 122-761B-30X-2, 11-12 cm, (?)Berriasian-Valanginian; (5) Sample 122-763B-50X-4, $115 \mathrm{~cm}$, Berriasian-lower Valanginian (B. reticulatum to E. torynum Zone). 4. Belemnopsis ex. gr. moluccana s.l. (Boehm, 1907); Sample 122-763C-13R-5, 27-28 cm, middle to upper Berriasian (D. lobispinosum to B. reticulatum Zone). 6. (?)Hibolithes sp.; left: ventral view, right: left lateral view (venter right); Sample 122-763B-48X-3, 48-49 cm, Berriasian (E. torynum Zone). 7. Duvalia cf. sakalava Besairie, 1930; left; ventral view, right: lateral view (venter right); Sample 123-766A-42R-2, 41-43 cm; Hauterivian (Cruciellipsis cuvillieri Zone). For each specimen, two views are presented. Left: ventral view, right: left lateral view (venter right). All specimens shown in the plate have been coated with ammonium chloride; magnification is $\times 1$. 